\title{
Beyond policy-making: institutional regimes, the state and policy implementation in the Irish case
}

\section{Anne O'Brien}

To cite this article: Anne O'Brien (2010) Beyond policy-making: institutional regimes, the state and policy implementation in the Irish case, Current Issues in Tourism, 13:6, 563-577, DOI: $10.1080 / 13683500903216626$

To link to this article: https://doi.org/10.1080/13683500903216626

曲 Published online: 18 Mar 2010.

Submit your article to this journal $\asymp$

Џlll Article views: 338

Citing articles: 6 View citing articles $₫$ 


\title{
Beyond policy-making: institutional regimes, the state and policy implementation in the Irish case
}

\author{
Anne O’Brien* \\ Department of Adult \& Community Education, NUI Maynooth, Co., Kildare, Maynooth 001, \\ Ireland
}

(Received 26 May 2009; final version received 24 July 2009)

\begin{abstract}
This article applies developmental state analysis to the Irish tourism industry between 1987 and 2007 and argues that the state generates growth by constructing institutions around the development project. Combining in-depth interviews of key players with extensive documentary analysis, the case study found that the relationship between state institutions and private sector coalitions was central to the development of the industry. These relationships were explained through the concept of interlocking regimes whereby regimes are constituted through the dimensions of power arrangements, policy paradigms, organisations and policy. The implementation of a development model is shaped by the extent to which a coalition and a state regime interlock to impose that model. This occurs when regimes interact strategically through some or all of the dimensions of both regimes. In the Irish case, the research found that new organisational alliances within the private sector disturbed the power arrangements underpinning the status quo. A new interlock between the state and the business class led to regime change and the display of authority by political leaders played a significant role in establishing a new regime with a new policy paradigm and goals for the sector, which facilitated the phenomenal growth of the sector.
\end{abstract}

Keywords: development state; politics and tourism; policy implementation; interlocking regimes; institutions; policy-making

\section{Introduction}

In recent decades, states have become increasingly engaged with tourism as a means of achieving economic development (Edgell, 1999; Hall, 1994, 1998, 2000) and academic debate has become more focused on the political aspects of this issue (Elliot, 1997; Hall, 1999; Hall \& Jenkins, 1995; Jenkins, 1999, 2001; Ritcher, 1983, 1994; William \& Shaw, 1998). However, the political features of the state's involvement with tourism development have not yet been fully explored within the literature. Analysts have closely examined political matters such as the policy-making process, policy networks and interest groups impacts on governments' roles in development (Anastasiadou, 2008; Butler, Hall, \& Jenkins, 1998; Edgell, DelMastro Allen, Smith, \& Swanson, 2008; Pforr, 2005, 2008; Treuren \& Lane, 2003; Tyler \& Dinan, 2001). But they have not yet exhaustively examined the broader issue of the complex institutional politics that underpin the state's involvement

*Email: anneobrien@kairoscomms.ie 
in tourism policy creation as well as implementation. This article aims to address this issue by applying developmental state analysis to the tourism industry. This latter perspective argues that the state generates growth by constructing institutions around the development project. More specifically, it proposes that two linked features of the state underpin institutional capacity, a degree of bureaucratic autonomy and institutional links across public and private sectors (Evans, 1995; Johnson, 1982). It is this key insight that the article will examine in relation to the Irish tourism industry between 1987 and 2007. Combining indepth interviews of key players with extensive documentary analysis, the case study found that the relationship between state institutions and private sector coalitions was central to the development of Irish tourism. These relationships were explained through the concept of interlocking regimes. Regimes are constituted in four dimensions (Wilson, 2000), power arrangements, policy paradigms, organisations and policy, within both the private sector and the state institutions involved in the development project. The implementation of a development model is shaped by the extent to which a coalition regime and a state institutional regime interlocked to impose that model. Interlock occurs when a political coalition's regime interacts strategically with a state institutional regime, or vice versa, through some or all of the dimensions of both regimes. In the Irish case, the research found that new organisational alliances within the private sector disturbed the power arrangements underpinning the status quo. A new interlock between the state and the business class led to regime change and the display of authority by political leaders played a significant role in establishing a new regime with a new policy paradigm and goals for the sector.

In outlining this argument the key contributions made by the study are: firstly, it moves beyond examining government roles in the policy-making process, instead the study examines the nature of state and private sector interactions which underpin policy creation but also vitally, policy implementation; secondly, it challenges the classic presentation of the Irish tourism 'boom' which proposes that it was achieved because of the liberalisation of air access between Ireland and the UK and, as Deegan and Dineen (2000, p. 163) put it, 'through a benign combination of good luck, favourable external and internal conditions and supportive government policies aided by resource transfers from the European Union'. Undoubtedly, the liberalisation of airfares, government support and EU structural funds were all vital components that generated growth, but a key point nonetheless remains that these factors were all politically mediated, for better or worse, by the Irish state, and the state's role in both promoting and preventing development opportunities for tourism needs to be acknowledged and explored in more detail. Thirdly, the study presents new elements to theoretical accounts of the politics of developmental change. These latter innovations include the use of the interlocking regime as a means of conceptualising the state, the private sector and their interactions, which rejects the tendency in the tourism and development literatures to treat these variables as objective or fixed entities. Finally, the research points to a gap in the existing work of developmental state theorists, which is to incorporate further examinations of tourism development in the range of subjects for analysis.

\section{Development and the tourism literature}

'The mainstream of tourism research has either ignored or neglected the political dimension of the allocation of tourism resources, the generation of tourism policy, and the politics of tourism development' (Hall, 1994, pp. 2-7). Perhaps in response to this challenge in the early 1990s, some tourism analysts have in recent years examined the political economy of tourism and its development more closely (Dredge, 2001; Dredge \& Jenkins, 2007; Hall, 1998, 2000; Hall \& Jenkins, 1995; Jenkins \& Hall, 1997). This analysis has been 
conducted in part through studies of individual countries' tourism development policies (Chambers \& Airey, 2001; Kerr, 2003; Wong, Bauer, \& Wong, 2008). For instance, Deegan and Dineen $(1997,2000,2003)$ have examined the historical evolution of policy in Ireland and the 'organizational factors and the policy instruments applied to develop the sector', which were analyzed 'against the background of changing international demand trends \& EU government support for investment in the industry' (1997, p. 6). Other analysts examine tourism development more broadly in terms of the evolution of the policy-making process (Anastasiadou, 2008; Edgell et al., 2008; Michael, 2001; Pforr, 2005; Treuren \& Lane, 2003; Tyler \& Dinan, 2001). In this vein, Michael (2001) and Edgell et al. (2008) advocate the use of public choice theory (Buchannan \& Tullock, 1962) as a mechanism for understanding the relationships of bureaucrats and special interest groups in policy-making. Public choice theory proposes that political decisions are made, not in the public interest, but rather in the best interests of those making them (Edgell et al., 2008, pp. 263-264). Edgell et al. further elaborate that bureaucrats are motivated by achieving the mission of their agency and rely on special interest groups to influence the legislature, which leads to the potential for bureaucrats to be captured by interest groups (p. 264).

While public choice theory recognises the roles of the state and private sector in tourism policy-making, it underspecifies the exact manner in which these agencies engage to generate development. An alternative examination of that relationship is offered by Hall (2008, p. 165) who notes that the state often acts in public-private partnerships, which may promote greater efficiency and cooperation in achieving economic goals, but may alternatively act to narrow policy perspectives and to limit the role of stakeholders to that of industry rather than community. Davis, Wanna, Warhurst and Weller (1993) note that partnership is used because it reduces the dependency of public enterprises on public budgets, reduces public debt by selling state assets and increases efficiencies through commercialisation. But Dredge and Jenkins (2007, p. 144) note that 'governments have yielded to the private sector too much discretion for making decisions that affect the public interest'. Treuren and Lane (2003) further extend the partnership approach to propose that tourism planning is a process that occurs within and between three locations, the individual tourism organisation, the industry and within the state. However, more recent analyses have suggested a need to be more 'encompassing and discriminating' in describing the policy process, and analysts have moved away from overly schematic analysis of the policy 'structure' to explore in more detail the 'complex, diffuse and non-rational nature of the policy process' as well as the multiplicity of actors involved, through studies of tourism policy networks (Pforr, 2005, p. 334).

These studies refer to actors and relationships in the policy process that suggest the presence of many communities and different types of networks in tourism development (Atkinson \& Coleman, 1989, p. 154). Policy networks are understood as power dependency relationships, which exist between government and interest groups, in which resources are exchanged (Börzel, 1997, p. 2). Tyler and Dinan (2001) propose that within networks, interested groups try to influence government policy at the interface between producer groups, countervailing groups and autonomous state agencies (2001, p. 217). They further argue that the tourism policy network is dominated by government, which strategically directs policy, with sub-networks applying resources to generate collaborations with government bureaucracy and decision makers (2001, pp. 244-245). Pforr (2005, p. 336) uses a network approach to place the focus on 'the participants in the policy-making process, their relationships as well as the structural context in which these take place'. More radically however, Pforr (2005) argues for a combination of Easton's (1965) policy system 
with policy cycle and policy network models to create a process-oriented model of policymaking that recognises and captures the complexity of influential factors such as policy environment, time horizons and the importance of public and private sector actors in the process.

These studies all provide considerable insights into the policy environment and the engagements of networks within that environment, outlining in detail how those relationships function. However a general criticism of the networks approach is that it tends to be descriptive rather than explanatory. Moreover, although Pforr's (2005) analysis does much to address the complexity of policy-making, his study is less focused on the issue of policy implementation, which is dealt with in a mainly descriptive way, by detailing the phase of implementation as part of the policy cycle, but the framework does not explain what political factors or players determine the implementation of policy. Thus, analysis of tourism policy-making to date successfully recognises and captures the complexity of influential network factors but, with the exception of Dodds (2007), they underspecify the exact manner in which agencies engage to generate development outcomes, or as Pforr (2005, p. 338) puts it how exactly the political system transfers inputs into outputs'. They do not fully explore how politics influences not just policy-making but also implementation. Thus, the politics underlying the interactions of the state and private sector within development strategy can be further interrogated and it is to the examination of that issue that this paper is directed.

\section{The developmental state: constructing institutional capacity}

If the gaps in the tourism literature outlined above are to be addressed then the debate needs to engage with a literature that has comprehensively examined the state's role in economic development. Economic sociologists have outlined the manner in which states affect developmental performance. The main claim made is that the power of the developmental state is dependent on its relationship with the private sector as well as on its own institutional capacity to effectively promote development (Johnson, 1982). Thus, a number of statestructural theories emphasise the impact of the state's structure and its actions on policy, but they do not 'insist on the autonomy of the state vis-à-vis societal pressure. Instead they accord interest groups, political parties, and other actors outside the state an important role in the policy process' (Hall, 1993, p. 276). The key insight for understanding tourism development is that states' roles in development are determined by the institutional nature of the state (Evans, 1995; Onis, 1991; Wade, 1990). Two linked features of the state underpin this institutional element of state development capacity. Firstly, a degree of bureaucratic autonomy and secondly, institutional links across public and private sectors (Onis, 1991). The coexistence of an independent bureaucracy and links between the public and private sectors means that the state and bureaucratic elites can develop independent national goals and translate these broad national goals into effective development action (Onis, 1991). Evans explains this combination in terms of 'embedded autonomy' where the state achieves autonomy by channelling the bureaucracy to the pursuit of developmental goals, but the state is also "embedded in a concrete set of social ties that bind the state to society and provide institutionalised channels for the continual negotiation and renegotiation of goals and policies' (Evans, 1995, p. 59). It is this capacity for institutional configuration that explains why some societies have been more successful than others in achieving growth (Evans, 1995, 1997; Sabel, 1994; Smelser \& Swedberg, 2005).

The state developmental literature addresses not only the bureaucratic aspects of state capacity but also examines the manner in which coalitions are constructed and maintained 
across the state and commercial classes. Thus, the concept 'developmental state' means that the public and private sides use each other in a mutually beneficial relationship in order to achieve developmental goals. When the developmental state is working well, it is a 'catalytic' and networked agency and the business class respond to incentives and disincentives that the state establishes. 'This is not an easy combination to put together, but when it is done properly, it can produce miracles of economic development' (Woo-Cummings, 1999, p. 60). Thus, if state developmentalism is centrally determined by the state's capacity to generate institutional configurations it becomes important to clearly outline what is meant by an institution. Various institutionalists distinguish among institutional dimensions from within particular paradigms (Campbell, 2004) but typically institutions are understood to comprise formal and informal dimensions or to comprise regulative, normative or cultural-cognitive pillars (North, 1990, 1998; Orren \& Skowronek, 1994). However, there is little consensus on connecting these dimensions to any particular definition of an institution. Wilson (2000) draws on an international and regulatory regime literature (Doughterty \& Pfaltzgraff, 1997; Espang-Anderson, 1993; Harris \& Milkis, 1996; Kratochwil \& Ruggie, 1997) in order to propose that policy regimes comprise four dimensions: Power arrangements, which 'entails the presence of one or more powerful interest groups supporting the policy regime' and which may occur in many different patterns (Wilson, 2000, p. 257); Policy paradigm, which is the ideology or set of assumptions that shapes the way that problems are perceived or defined, the types of solutions offered and the kinds of policy proposed (Gusfield, 1981); Organisations, as they exists within government, within policymaking arrangements and within the implementation structure; Policy goals which both embody the goals of the policy regime and entails the 'rules and routines of the implementing agency' (Wilson, 2000, p. 258). Wilson's definition of policy regimes can be used to understand the dimensions of institutions. Thus, institutions are defined here, as regimes comprised of the four dimensions of policy paradigms, policy goals, power arrangements and organisations. Determining how the developmental state influences tourism development becomes a matter of examining the institutional configuration that is constructed, at these various dimensional levels, around the development project.

\section{Methodology}

The article draws on a case study analysis conducted between 2004 and 2006. Case studies attempt to provide a multi-dimensional picture of the case and are useful in explorations of relationships, patterns of influence, and micro-political issues (Yin, 1989). Within the case study a grounded theory approach (Glasser \& Strauss, 1967) was used to guide the data collection, to create conceptual categories, to manage the data analysis, to demonstrate relationships between conceptual categories and to develop the theoretical framework (Charmaz, 2003, p. 311). The timeframe delineation of the case was the period between 1987 and 2007. This particular 20-year period was chosen because Irish tourism underwent significant and consistent year-on-year growth over this timeframe, from a base number of tourism arrivals at 2.4 million, and revenue earnings of $£ 1153$ million ( $€ 1459$ million) to arrivals of 7.7 million, and revenue earnings of $€ 6.45$ billion. Data were collected through documentary analysis and semi-structured interviews with key players. The interviews were conducted with a sample of eight key players in government departments, state agencies, and private sector organisations concerned with tourism development. The sample was collated through preliminary interviews with informants who were incumbents in senior positions in leading state and private sector organisations. These initial interviews explored participants' opinions and accounts of tourism development. On that basis further topics 
and questions emerged and other potential interviewees were named and these avenues were subsequently pursued in further interviews. In this way, the data collection was very much focused on a key cohort who were at the centre of the development process. Three further interviews were sought but declined due to illness. Those interviewed included: Michael McNulty, former Director General of Bord Fáilte; Paddy Teahon, former Secretary General in the Department of An Taoiseach; a senior civil servant from Department of Tourism; Paul O' Toole, Chief Executive of Tourism Ireland; John Power, Chief Executive of the Irish Hotels Federation (IHF); Jim Flannery, former Chief Executive of the IHF; Brendan Leahy and Eileen O' Mara-Walsh, former Chief Executives of the Irish Tourism Industry Confederation (ITIC). The sampling process produced a small cohort of interviewees but all persons named by key players as relevant were approached, moreover the resultant data were derived from state, semi-state and private sector organisations and in this regard were both balanced and representative.

The manner in which the semi-structured interviews were conducted allowed for flexible and adaptable means of data collection, enabling follow-up questions on interesting lines of inquiry, and allowed for a greater understanding of nuances and context. Interviews were taped and transcribed later. Interviews generated both agreements and contradictions about tourism's development, which further qualified and enriched both the documentbased information and the overall qualitative argument. The grounded theory approach to the process meant that as data emerged it was analysed and initial accounts were further interrogated during subsequent field interviews. In this way, the analytic incisiveness of the resultant analysis was strengthened. The generalisation to theory from interview data was further underpinned by very extensive documentary analysis, which incorporated all official and archival state documents relating to tourism development in Ireland since the foundation of the state, all organisational records that were available through libraries, databases or directly from organisation's archives, annual reports, policy reports and papers from both public and private sector tourism organisations and legislative documents. Issues of authenticity were unproblematic as most documents were deposited in state archives, but there were some concerns around the issue of representativeness as some private sector organisations were less inclined to archive documents than state agencies. Throughout the analysis of the documents, issues of form, structure, content and potential absences were brought to bear and documents were read as manifestations of the ideologies underpinning their source organisations. The interview and documentary data were organised across a timeordered matrix of the sector's development between the late 1970s and 2007 and categorised according to their origin. Patterns and regularities as well as contradictions emerged as the data were coded, which posited a structure for the overall analysis. The findings from the documentary data were checked against interview data for correlations, verifications or disparities. The data analysis thus moved between descriptions of events that underpinned the creation of development strategies and the classification of these events into themes and categories, which were then coded in relation to the theoretical framework outlined. The resultant, detailed case study analysis of the political economy of the growth of Irish tourism, incorporating a developmental state perspective, is outlined below.

\section{The Irish case}

Between 1987 and 2007 Irish tourism grew significantly from tourism arrivals of 2.4 million, with 69,000 people employed, to a peak of tourism arrivals of 7.7 million, with 322,000 people employed. This growth was facilitated by the creation of an institutional developmental regime between the Irish State and the private sector, which radically 
transformed the power arrangements, the policy paradigm and organisational structures of the sector, resulting in the successful generation and implementation of radical policy goals for the sector. The remainder of this article outlines the manner in which this institutional development regime was constructed by the various political coalitions involved in the sector and notes the factors that impacted upon both the generation and implementation of the tourism development strategy. The institutional regime concerned with the development of Irish tourism began to change in the late 1970s at an organisational level, when the most dominant of the tourism organisations at the time, the $\mathrm{IHF}^{1}$ was consolidated under the directorship of a new chief executive, who had been recruited from the state national tourism agency, Bord Fáilte. Change within the IHF was further underpinned by the creation of a new, networked organisation to represent the industry, the ITIC. ${ }^{2}$ These organisations initiated a shift in thinking on the potential of the tourism industry for economic development, which resulted in the creation of an organisational alliance with the dominant conservative political party, Fianna Fáil (ITIC, 1989). Following the election of that party to parliament, the power arrangements underpinning tourism development changed fundamentally. With the Taoiseach ${ }^{3}$ and his government department acting as a champion for tourism development, the state tourism agency was redirected into a partnership-style engagement with the private sector. Further organisational changes resulted in the generation of radical policy and targets for growth. Stationery Office, 1988, 1989, 1999. The advent of EU structural funds for tourism development, and the bureaucratic procedures that accompanied the funds, led to the highly efficient implementation of the targets for growth. Thus, because of changes in the institutional regime concerned with tourism development, that is: changes in the organisational network, in the power arrangements, changes in understandings of the economic importance and benefits to be derived from tourism, and changes in tourism policy generation and implementation practices, the entire institutional basis of tourism development was radically altered, which contributed to the creation of a state developmental project that was highly effective in generating growth.

\section{Organisational change and policy paradigm shifts}

The genesis of change originated within the IHF, when in 1978 they appointed a new chief executive with a remit to consolidate the organisation. Also in the early 1980s O' Mara Walsh, founded a new industry network ITIC, which aimed to consolidate and unite the entire private sector. As Brendan Leahy, former Chief Executive of ITIC notes about the organisation at that time:

\footnotetext{
What I felt was that we needed an industry that speaks with a single voice, so that if there are any statements being issued on tourism and dealings with government it goes through one body ... the only hope that you have of holding people together on a single voice on policies is to keep at a strategic level .... ITIC got together in the early 1980s with a pretty good constitution and deliberately kept the focus on national policy rather than trade difficulties ... if you come together to form a strong group you can influence policy .... The second thing was that a policy must be industry led, in other words if a policy emerged and we weren't consulted we would say sorry the industry isn't part of this ... The third thing was that the industry should participate in national structures. That's terribly important. (Leahy)
}

By 1986, the IHF was adequately consolidated as an organisation to turn its attention to the fundamental underlying problem for the sector - inadequate growth. As Flannery, the IHF Chief Executive notes 'There wasn't enough growth to sustain the hotel sector and it 
really wasn't going anywhere'. This realisation essentially initiated a shift amongst the private sector in the key vision or policy paradigm that underpinned the sector. While the IHF held the rotating chairmanship of ITIC in 1986 it commissioned a study into the possibility of doubling tourism numbers and revenue Stokes, Peat, and Davy, 1986. Flannery recounts:

The question we put to the consultants to find out for us was could Ireland's tourism double in five years? ... The response was yes the market could yield this ... One of the primary impediments was access and the cost of access. But the financial return on the jobs creation would be much greater than a similar investment in agriculture or in manufacturing ... (Flannery)

The findings of this report led to a fundamental shift in the state's ideological position on tourism development when one political party in particular responded positively to the report. Flannery explains the IHF's strategy for approaching the state apparatus with its proposal. Late in 1986 a general election had been called:

John Bruton was leading Fine Gael, Dessie O’ Malley was leading the Progressive Democrats, MacGiolla was leading Labour, and Charlie Haughey was leading Fianna Fáil. We took the report outcome to all of them ... The Labour Party disappointed us .... Dessie O' Malley attacked us for not attacking Aer Lingus ... Charlie was the one that had the positive response. He said 'Could I make it a plank in the manifesto?' We said ok it's your platform. So he ran with it. (Flannery) ${ }^{4}$

Flannery further notes 'Fortunately they were elected and John Wilson became Minister for Tourism and was instructed by the Taoiseach to get on with it'. The outcome was a report Putting growth back into tourism, which outlined the new Fianna Fáil government's thinking on tourism development. The report noted that 'Revitalising tourism must be a top national priority' (Fianna Fáil, 1987, p. 3).

Thus a new institutional configuration focused on tourism development had begun to emerge because a cooperative interlock had been created at an organisational level between the IHF and Fianna Fáil. This connection led to a further fundamental shift in how the state perceived tourism's potential for economic development and growth. The role of two key players, Flannery and Haughey, in the creation of the initial organisational connection is significant. Aldrich (1999) and Kingdon (1995) have referred to such key individuals as institutional entrepreneurs and have proposed that they are normally responsible for recombining institutional elements in innovative ways. However, the conceptualisation of institutional regimes outlined here proposes that the main importance of these individuals is not only their individual entrepreneurial characteristics but also their position within the dimensions of an institutional regime and their roles in creating connections between the public and private sides of the development regime. Thus, the entrepreneurial qualities of the Taoiseach and the Chief Executive of the IHF were both central to change within tourism development, but not only because they were tourism 'champions' but rather because of their positions within the structures of the institutional regime, which facilitated the creation of new connections between the public and private sectors, which led to change in the tourism development strategy.

\section{Changing power arrangements}

The paradigm shift within the new government resulted in a further shift in the power arrangements within the sector. The private sector was increasingly included in policy creation and implementation. The state responded officially to recommendations made 
by an industry association in The national development plan 1988-1992. Moreover, the Department of An Taoiseach responded rapidly and significantly to inadequacies and tensions in the state tourism agency. In effect the central government consolidated its role as the generator of tourism policy and extended the level of involvement of the private sector, namely ITIC and IHF, to partnership status. Concurrently, Bord Fáilte was increasingly relegated to the role of coordinator for all regional and local bodies. This shift in emphasis resulted in a radical reappraisal of state organisations involved in tourism and in particular Bord Fáilte's role in the tourism sector. O'Mara Walsh notes that ITIC met with some resistance from Bord Fáilte:

You had Bord Fáilte and Bord Fáilte would have seen themselves as representing the industry, but it was a state agency ... and to a degree also at the time it was fairly autocratic ... They saw themselves as the patrons, the Godfathers ... (O'Mara Walsh)

The changes in private sector tourism organisations, the power arrangements surrounding them and the state's ideological shift in its approach to tourism development caused fundamental alterations in the state's role in tourism development, which significantly impacted upon the policy goals for tourism development, and their implementation, which also centrally involved the EU. The Irish State negotiated with the European Commission a very significant and fully costed strategy for the development of tourism, which resulted in the Operational Programme for Tourism 1989-1993. The advent of EU funding for tourism development had a profound influence on the development of the sector but also on the political coalition underpinning the sector's rapid growth. As McNulty notes, EU funding was:

... A key element because without that we would never have been able to get the product right. Government could have given us more money for marketing and so forth but that would not have built the foundation for the industry properly. So the EU Funds were critically important. (McNulty)

However, the administrative structures required by the funds also played a role in consolidating new state-private sector power arrangements for tourism. Leahy explains ITIC's role in the distribution of funding:

As part of the structural funds you had to have a consultant committee within the industry and ITIC had four people on that. So we had an industry sitting around the table and it monitored the distribution of the structural funds from tourism under the aegis of the Department and Brussels ... So we had a very good influence on how the funds were being applied to tourism ... It was monitored by the Department of Tourism ... and the Brussels people would attend all the meetings and would say their concerns and would make sure that the funds were directed in compliance with the EU regulations ... and then the EU would bring in consultants and evaluate after a year, year-and-a-half because it was dealing with targets. You had to get tourism growth, you had to get quality, you had to get regional distribution of tourism and all sorts of things. But it was a very good forum for case making, for how to direct funds to the benefit of the industry. I think if the industry wasn't there funds would still be distributed but they wouldn't have the same impact ... The whole European Regional Development Fund (ERDF) funds for tourism was a tremendous success because it leveraged an enormous investment on the private sector side even though it provided the seed money, it provided the incentive, it leveraged the investment ... (Leahy)

Commenting on the impact of the funding structures on the power arrangements and relations between state agencies and the private sector, Leahy further notes: 
We became involved in the ERDF committee and with the Department. We were in partnership with them on that committee and then we would work with them in between meetings. To be fair the Department were quite receptive after a while ... But I think the Tourist Board saw the emergence of ITIC as an erosion of their influence both with the department and within industry and certainly watched what ITIC were doing very carefully and they were members of ITIC which was quite interesting ... I think the tension would come first of all because of the fact that memberships of Bord Fáilte were all political appointments. The government of the day always appoints all of Bord Fáilte ... generally people were put on because they were pro-party ... Tension would emerge more in petty ways ... They were losing their status as a planning body. (Leahy)

From Bord Fáilte's perspective the ERDF committees were challenging as organisational partnerships. As McNulty comments:

You do have to establish that level of trust, because the private sector sometimes do not trust the government sector and vice versa. They see things from different perspectives so it takes, in my view, years to get that aligned so that there is a reasonable view by both sides ... When the ERDF partnerships were formed I made a rule indicating that no person from the tourist board or public sector could chair any of them. So they were all chaired by the private sector ... and this caused quite a lot of aggravation obviously for me because our people didn't like that because the opposite would have happened before. (McNulty)

The co-operation generated by the ERDF structures signalled a new departure in state agency and industry power relations, which came to be characterised as genuinely open networks between government departments, state agencies, and private sector organisations. For the IHF:

The coming of the Operational Programme for Tourism ... was when we broke down this barrier of 'them and us'. And since then there has been a willingness to continue this, pushed by the government; and the Ministers wanted it, they wanted industry onboard and the industry got more organised too in a sense ... and we're still very much involved in the lobbying issues; we have various policy inputs into things like National Development Plans; we would be strongly represented on the boards of Tourism Ireland and Fáilte Ireland. ${ }^{5}$ We would have ongoing dialogue with the department, the department work very closely with us now, there was a time when they didn't want to see you. Now nothing happens but they're talking about it. (Power)

For Bord Fáilte the success of the project also generated a change in agency - industry relations:

Once we achieved success in terms of getting $15 \%$ growth for the first 2 years, the industry then really became much more engaged because now they could see the confidence and trust in the whole process and leadership and in their own ability which was growing all the time ... and we were helping them at all those stages because no matter how good you are as a tourist board, you can never equal the capacity of the industry so you have to get the industry working with you. (McNulty)

Thus the state used the EU funding programmes to further 'define' and discipline both industry and its own tourism organisations and to centralise the state's development agenda.

The tendency to lead Bord Fáilte into increased interlock with the private sector was further underscored with the establishment of the National Tourism Council in 1993, which served to formally include the commercial sector in policy negotiations and to act in a briefing capacity to the Minister. Again in 1994 the government, and not the state 
agency, set the industry growth targets in the Second Operational Programme for Tourism 1994-1999. This plan proposed to achieve foreign earnings of (IR)£2250 million and to create a further 35,000 jobs (Stationery Office, 1994, p. 5). Bord Fáilte's role in tourism in general became increasingly defined as an implementation body but also more limited in the early years of the 2000s. By 2002, Tourism Ireland Ltd. took over from Bord Fáilte the responsibility for Tourism Brand Ireland and the marketing of the island of Ireland overseas. ${ }^{6}$ In May 2003, the Tourism Traffic Act 2003 established Fáilte Ireland as the new national tourism development authority, however the agency was limited to providing support services for the industry across a number of areas such as research, recruitment, education, and professional development. In the marketing area, Fáilte Ireland was to promote only domestic tourism and was to work in association with Tourism Ireland Ltd. on the international market. By 2003, the only body directly responsible for tourism policy was the government, with the Minister directly advised by private sector organisations. The state became increasingly embedded in the tourism industry at an institutional level during the late 1980s and early 1990s by weakening the hegemony of Bord Fáilte and by facilitating the private sector in accessing the policy-making process. Thus, in the late 1980s and 1990s the institutional landscape of the tourism sector was radically altered from a state-led, paternalistic, top-down approach to a co-operative, networked and interlocked approach which realised the instigation and implementation of a new development strategy.

\section{New policy goals}

Growth targets were increasingly ambitious and outcomes equally impressive. The departure point for a change in policy goals for the tourism industry had occurred with the first statement of specific targets for growth in the Programme for National Recovery in 1987, which proposed the doubling of tourism earnings and the creation of 25,000 jobs (Stationery Office, 1987). The following national development strategy, the Programme for Economic and Social Progress, in 1990 set targets for growth for 1991-1993 at an increase in visitor numbers from 1.4 to 4.5 million with the creation of 15,000 jobs (Stationery Office, 1990, p. 48). These targets were met and superseded in the Second Operational Programme for Tourism 1994-1998 which proposed to create a further 35,000 jobs, as well as extend the tourism season and improve the quality of service through training (Stationery Office, 1994, p. 5). The Tourism Development Strategy 2000-2006 set targets for 9 million tourist trips (Bord Fáilte, 2000). By 2003 tourism was generating 4.4\% of GNP and supporting 140,000 jobs (Department of Arts, Sport and Tourism, 2003; Fáilte Ireland, 2003). The final report of the Tourism Action Plan Implementation Group in 2006 noted, '... the statistics speak for themselves. The tourism industry provides direct employment for almost 150,000 workers. In 2005, it attracted 6.7 million overseas visitors. This level of foreign revenue earnings is equivalent to half the value of exports by all Irish-owned manufacturing companies' (Stationery Office, 2006, p. 1). By 2007, 20 years after the first change in the development regime, tourism arrivals were 7.7 million, the industry employed 322,000 people and revenue earnings from tourism were $€ 6.45$ billion (Fáilte Ireland, 2007). The Irish tourism industry had been transformed as a result of the creation of a highly effective state development institutional regime.

\section{Conclusion}

A key contribution made by this article is that its development state perspective moves beyond current tendencies in the tourism literature to examine the interactions of the 
state and the business class in terms of public-private partnerships (Davis et al., 1993; Hall, 2008) or networks (Pforr, 2005). The problem with approaching the interface of these parties in terms of partnership is that while it serves to describe the arrangement very well, it does not expose how the relationships are created, nor how the relationships function, nor do they adequately link to an explanation of how partnership actually generates or implements development strategies. As a response to this problem, the study focuses on an alternative conceptualisation of the interaction between the government and industry, which it frames in terms of the interlock of multi-dimensional regimes. This new understanding explores state and private sector interactions at the levels of organisations, power arrangements, policy paradigms and goals. The multi-level conceptualisation of the state, industry and their interactions offers scope to understand at a macro level not only how a state and private sector interlock is initially created but also how it functions to facilitate policy generation and implementation in a more detailed, complex or multi-dimensional way than the partnership approach, which accepts partnership as a somewhat unproblematic descriptive category. Nonetheless, although the framing of the state and private sectors as regimes, and their interactions in terms of interlock is a useful progression of the debate around state and business interactions for development, nonetheless there is scope for further exploration of the political process and practices involved in creating interlocks, at both meso- and microlevels.

Furthermore, while some of the complexity of the interactions between state and business coalitions within development projects has been discussed in the tourism literature, through a networks approach to tourism development, this study builds upon that analytic approach. This article incorporates a general acceptance of tourism development as a networked phenomenon but the main departure from the network approach is at the level of explanation. Rather than simply describing the existence of a developmental network this study explores instead the manner in which the network, or rather interlock, of developmental regimes was created. Thus, it explores the origins of interlocks across the dimensions of policy paradigms, organisations, power structures and policy goals, and explores the manner in which connections between the state and industry are created through interlocks, which act as the equivalent of nodal points on a network. Thus, while this study recognises that developmental programmes are networked it conceptualises the networks differently, as institutional regimes. In this way, the study adds named dimensions to understandings of networks and focuses on the points at which interconnection occurs in order to explain the origins and functions of the regime connections rather than merely describing them. Moreover, the article moves beyond the current tendency in the literature to limit analyses of tourism partnerships or networks to the policy-making process, in so far as this study also examines policy implementation. Dodds $(2007$, p. 297) emphasises that 'research on the implementation of tourism policy is weak' and there are 'multiple needs for research on this topic'. While Dodds usefully addresses the implementation of policy at local level, this study addresses the issue at national level. Moreover, it focuses on generating some conceptualisations of the institutional aspects of policy implementation. This study names the regimes and the dimensions through which the state and industry engage on policy implementation. The implications for further research in this regard are numerous, most particularly this framework could be applied across other cases of tourism development to understand the extent to which the frameworks generalisations are valid beyond the limitations of the Irish case.

This article demonstrates that a development state approach has much to offer with respect to generating frameworks for understanding tourism development. With regard to the Irish tourism literature and the developmental state literature, this study challenges 
both. The Irish tourism 'boom' is usually explained in terms of the liberalisation of access to Ireland and the advent of EU structural funds but these factors were both mediated through state decisions and thus the paper highlights the need to acknowledge and explore states' roles in tourism development more thoroughly. With regard to the developmental state literature, the study elaborates a new theoretical approach to the politics of developmental change, which invokes interlocking regimes as a conceptualisation of state and private sector interactions. This approach avoids the development literature's tendency to reify these variables and challenges institutional analysts to examine the mechanisms of change more thoroughly at the level the state and industry interactions. Similarly, the research highlights the fact that developmental state theorists have somewhat neglected service sector industries in general and tourism in particular, despite the fact that it has been a global growth sector. The study makes the case for placing continued emphasis on a more rigorous analysis of the institutional politics of tourism development.

\section{Notes}

1. The Irish IHF is the national organisation of the hotel and guesthouse industry.

2. ITIC is a representative body for the industry and focuses on the economic development of tourism.

3. An Taoiseach is the Irish prime minister.

4. Fine Gael describes itself as a political party of the 'progressive centre'. Progressive Democrats were a free market liberal party, dissolved in 2009. Labour Party is a democratic socialist and social democratic party. Fianna Fail has been the dominant party in Ireland since the 1930s. Aer Lingus is the national airline.

5. Tourism Ireland coordinates with Fáilte Ireland in the Republic and the Northern Ireland Tourist Board on product development and marketing.

6. Tourism Brand Ireland is a destination branding strategy managed by Tourism Ireland.

\section{References}

Aldrich, H.E. (1999). Organisations evolving. Thousand Oakes, CA: Sage.

Anastasiadou, C. (2008). Stakeholder perspectives on the EU tourism policy framework. International Journal of Tourism Research, 10(3), 193-291.

Atkinson, M.M., \& Coleman, W.D. (1989). Strong states and weak states: Sectoral policy networks in advanced capitalist economies. British Journal of Political Science, 19(1), 46-67.

Bord Fáilte. (2000). Tourism development strategy 2000-2006. Dublin: Stationery Office.

Börzel, T.A. (1997). What's so special about policy networks? An exploration of the concept and its usefulness in studying European governance. European Integration Online Papers, 1(16), 1-24.

Buchannan, J.M., \& Tullock, G. (1962). The calculus of consent: Logical foundations of constitutional democracy. Ann Arbor: University of Michigan Press.

Butler, R., Hall, C.M., \& Jenkins, J. (Eds.). (1998). Tourism and recreation in rural areas. Chichester, UK: John Wiley.

Campbell, J. (2004). Institutional change and globalization. Princeton University Press.

Chambers, D., \& Airey, D. (2001). Tourism policy in Jamaica: A tale of two governments. Current Issues in Tourism, 4(2-4), 94-120.

Charmaz, K. (2003). Qualitative interviewing and grounded theory analysis. In J.A. Holstein \& J.F. Gubrum (Eds.), Inside interviewing: New lenses, new concerns (pp. 311-323). Thousand Oakes, CA: Sage.

Davis, G., Wanna, J., Warhurst, J., \& Weller, P. (1993). Public policy in Australia (2nd ed.). St Leonards, NSW: Allen \& Unwin.

Deegan, J., \& Dineen, D. (1997). Tourism policy and performance. London: International Thompson Business Press.

Deegan, J., \& Dineen, D. (2000). Developments in Irish tourism, 1980-1996. International Journal of Tourism Research, 2(3), 163-170. 
Deegan, J., \& Dineen, D. (2003). The changing contribution of tourism in a dynamic economy: The case of Ireland. Tourism Economics, 9(2), 147-164.

Department of Arts, Sport and Tourism. (2003). Tourism policy review group report. Dublin, Ireland: Stationery Office.

Dodds, R. (2007). Sustainable tourism and policy implementation: Lessons from the case of Claviá, Spain. Current Issues in Tourism, 10(4), 296-322.

Doughterty, J., \& Pfaltzgraff, R. (1997). Contending theories of international relations: A comprehensive survey. New York: Longman.

Dredge, D. (2001). Local government tourism planning and policy-making in New South Wales: Institutional development and historical legacies. Current Issues in Tourism, 4(2-4), 355-380.

Dredge, D., \& Jenkins, J. (2007). Tourism planning and policy. Brisbane, QLD: John Wiley.

Easton, D. (1965). A system analysis of political life. New York: Wiley.

Edgell, D.L. (1999). Tourism policy: The next millennium. Champaign, IL: Sagamore Publishing.

Edgell, D.L., DelMastro Allen, M., Smith, G., \& Swanson, J.R. (2008). Tourism policy and planning: Yesterday, today and tomorrow. Oxford, UK: Butterworth Heinemann.

Elliot, J. (1997). Tourism: Politics and public sector management. London: Routledge.

Espang-Anderson, G. (1993). The three worlds of welfare capitalism. Princeton University Press.

Evans, P. (1995). Embedded autonomy: States and industrial transformation. Princeton University Press.

Evans, P. (1997). State, society, synergy: Government action and social capital in development. Berkley: University of California Press.

Fáilte Ireland. (2003). Tourism facts. Retrieved May 5, 2009, from http://www.failiteireland.ie

Fáilte Ireland. (2007). Tourism facts. Retrieved May 5, 2009, from http://www.failiteireland.ie

Fianna Fáil. (1987). Putting growth back into tourism. Dublin, Ireland: Author.

Glasser, B., \& Strauss, A. (1967). The discovery of grounded theory. Chicago: Aldine Publishing.

Gusfield, J. (1981). The culture of public problems. Chicago University Press.

Hall, P.A. (1993). Policy paradigms, social learning \& the state: The case of economic policymaking in Britain. Comparative Politics, 25(3), 275-296.

Hall, C.M. (1994). Tourism and politics: Policy, power \& place. London: John Wiley.

Hall, C.M. (1998). Tourism: Development, dimensions and issues (3rd ed.). South Melbourne, VIC: Addison Wesley Longman.

Hall, C.M. (1999). Tourism and politics, policy, power \& place. Chichester, UK: Wiley \& Sons.

Hall, C.M. (2000). Tourism planning (1st ed.). Harlow, UK: Prentice Hall.

Hall, C.M. (2008). Tourism planning: Policies, processes and relationships (2nd ed.). Harlow, UK: Prentice Hall.

Hall, C.M., \& Jenkins, J.M. (1995). Tourism and public policy. London: Routledge.

Harris, R., \& Milkis, S. (1996). The politics of regulatory change: A tale of two agencies. New York: Oxford University Press.

Irish Tourist Industry Confederation. (1989). Doubling Irish tourism: A market-led strategy. Dublin, Ireland: Author.

Jenkins, J. (1999, 30 August-2 September). Tourism and transformations in Australian political economy. The role of the state, policy shifts and corporate power, Paper presented at the tourism policy and planning conference, Oamaru, New Zealand.

Jenkins, J. (2001). Editorial. Current Issues in Tourism, 2(2-4), 69-77.

Jenkins, J., \& Hall, C.M. (1997). Tourism planning and policy in Australia. In C.M. Hall, J. Jenkins, \& G. Kearsley (Eds.), Tourism planning and policy in Australia and New Zealand (pp. 37-48). Sydney, NSW: Irwin.

Johnson, C. (1982). MITI and the Japanese miracle. Stanford University Press.

Kerr, W.R. (2003). Tourism public policy and the strategic management of failure. Oxford, UK: Pergamon.

Kingdon, J. (1995). Agendas, alternatives, and public policies (2nd ed.). New York: Harper Collins.

Kratochwil, F., \& Ruggie, J.G. (1997). International organization: The state of the art. In P.F. Diehl (Ed.), The politics of global governance: International organizations in an interdependent world. Boulder, CO: Lynne Rienner.

Michael, E.J. (2001). Public choice and tourism analysis. Current Issues in Tourism, 4(2-4), 308-330.

North, D.C. (1990). Institutions, institutional change and economic performance. New York: Cambridge University Press. 
North, D.C. (1998). Five propositions about institutional change. In J. Knight \& I. Sened (Eds.), Explaining social institutions (pp. 15-26). Ann Arbour: University of Michigan Press.

Onis, Z. (1991). The logic of the developmental state. Comparative Politics, 24(1), 109-126.

Orren, K., \& Skowronek, S. (1994). Beyond the iconography of order: Notes for a 'new institutionalism'. In L.D. Dodd \& C. Jillson (Eds.), The dynamics of American politics (pp. 311-330). Boulder, CO: Westview.

Pforr, C. (2005). Three lenses of analysis for the study of tourism public policy: A case from northern Australia. Current Issues in Tourism, 8(4), 323-343.

Pforr, C. (2008). Tourism in the northern territory: Caught in an intergovernmental quagmire. Public Policy, 3, 159-174.

Ritcher, L.K. (1983). Tourism politics and political science: A case of not so benign neglect. Annals of Tourism Research, 10(3), 313-335.

Ritcher, L.K. (1994). The political dimensions of tourism. In J.R.B. Ritchie \& C.R. Goeldner (Eds.), Travel, tourism and hospitality research (2nd ed., pp. 219-231). New York: Wiley.

Sabel, C. (1994). Learning by monitoring: The institutions of economic development. In N.J. Smelser \& R. Swedberg (Eds.), The handbook of economic sociology (pp. 137-165). New York: Russell Sage Foundation; Princeton University Press.

Smelser, N.J., \& Swedberg, R. (Eds.). (2005). The handbook of economic sociology (2nd ed.). New York: Russell Sage Foundation; Princeton University Press.

Stationery Office. (1987). Programme for national recovery. Dublin, Ireland: Author.

Stationery Office. (1988). National development plan 1988-1992. Dublin, Ireland: Author.

Stationery Office. (1989). Operational programme for tourism 1989-1993. Dublin, Ireland: Author.

Stationery Office. (1990). Programme for economic and social progress. Dublin, Ireland: Author.

Stationery Office. (1994). Second operational programme for tourism 1994-1999. Dublin, Ireland: Author.

Stationery Office. (1999). National development plan. Dublin, Ireland: Author.

Stationery Office. (2006). Tourism action plan implementation group report. Dublin, Ireland: Author.

Stokes, K.C., Peat, M., \& Davy, K.M. (1986). Tourism working for Ireland: A plan for growth. Dublin, Ireland: Stokes, Kennedy, Crowley.

Treuren, G., \& Lane, D. (2003). The tourism planning process in the context of organised interests, industry structure, state capacity, accumulation and sustainability. Current Issues in Tourism, 6(1), $1-22$.

Tyler, D., \& Dinan, C. (2001). The role of interested groups in England's emerging tourism policy network. Current Issues in Tourism, 4(2-4), 210-252.

Wade, R. (1990). Governing the market: Economic theory and the role of government in East Asian industrialization. Princeton University Press.

Williams, A., \& Shaw, G. (1998). Tourism and economic development (3rd ed.). Oxford: John Wiley $\&$ Sons.

Wilson, C. (2000). Policy regimes policy change. Journal of Public Policy, 20(3), 247-274.

Wong, E.P.Y., Bauer, T.G., \& Wong, K.F. (2008). A critical comparison of tourism policies of Hong Kong and Singapore. International Journal of Tourism Research, 10(3), 193-291.

Woo-Cummings, M. (1999). The developmental state. Ithaca, NY: Cornell University Press.

Yin, R.K. (1989). Case study research: Design and methods. New Delhi: Sage. 